\title{
A Direct Electron Transfer-Based Glucose/Oxygen Biofuel Cell Operating in Human Serum
}

\author{
V. Coman ${ }^{1}$, R. Ludwig ${ }^{2,3}$, W. Harreither ${ }^{3}$, D. Haltrich ${ }^{3}$, L. Gorton ${ }^{1}$, T. Ruzgas ${ }^{4}$, \\ and S. Shleev $4,5 *$ \\ 1 Department of Analytical Chemistry/Biochemistry, Lund University, 22100 Lund, Sweden \\ 2 Research Centre Applied Biocatalysis, 8010 Graz, Austria \\ 3 Department of Food Sciences and Technology, BOKU-University of Natural Resources and Applied Life Sciences, 1190 Wien, Austria \\ ${ }^{4}$ Biomedical Laboratory Science, Health and Society, Malmö University, 20506 Malmö, Sweden \\ 5 Laboratory of Chemical Enzymology, A.N. Bach Institute of Biochemistry, 119071 Moscow, Russia
}

Received June 10, 2009; accepted August 11, 2009

\section{Abstract}

We report on the fabrication and characterisation of the very first direct electron transfer-based glucose/oxygen biofuel cell (BFC) operating in neutral glucose-containing buffer and human serum. Corynascus thermophilus cellobiose dehydrogenase and Myrothecium verrucaria bilirubin oxidase were used as anodic and cathodic bioelements, respectively. The following characteristics of the mediator-, separator- and membrane-less, a priori, non-toxic and simple miniature
BFC, was obtained: an open-circuit voltage of 0.62 and $0.58 \mathrm{~V}$, a maximum power density of ca. 3 and $4 \mu \mathrm{W} \mathrm{cm}{ }^{-2}$ at 0.37 and $0.19 \mathrm{~V}$ of cell voltage, in phosphate buffer and human serum, respectively.

Keywords: Bilirubin Oxidase, Cellobiose Dehydrogenase, Direct Electron Transfer, Enzymatic Fuel Cell, Implantable Device

\section{Introduction}

It is inconceivable that already four decades ago, Beltzer and Batzold predicted a significant role of implantable biofuel cells (BFCs) operating on fuels and oxidants present in blood plasma as potential sources of electrical energy for artificial devices [1]. Much research and a large number of review articles on the design and characterisation of miniature BFCs based on mediated electron transfer (MET) have been published [2-8]. In spite of the obvious advantages of $\beta$-D-glucopyranose/oxygen BFCs (glucose $/ \mathrm{O}_{2}$ BFCs) based on direct electron transfer (DET) reactions as power sources for implantable devices (i.e. less-toxicity due to the absence of redox mediators, simple construction and ability for significant miniaturisation), there is no published work describing a mediator-, cofactor- and membrane-less BFC operating in human physiological liquids. Moreover, there are only few reports describing the performance of even well-studied mediator or/and cofactor-based glucose $/ \mathrm{O}_{2}$ BFCs in complex biological liquids, i.e. in human serum $[9,10]$. Our previous intensive investigations of the DET properties of different oxi- doreductases, including carbohydrate dehydrogenases [11, 12] and blue multicopper oxidases (BMCO) [13], allowed us to fabricate and characterise the very first DET-based glucose $/ \mathrm{O}_{2}$ BFC optimally working at $\mathrm{pH} 4.5$ [14]. Importantly, the basic characteristics of the non-optimised DET-based BFC were significantly better compared to the MET-based lactose $/ \mathrm{O}_{2} \mathrm{BFC}$ constructed using similar bioelements (cf. lactose $/ \mathrm{O}_{2}$ BFCs in Table 1). These DET- and MET-based devices, however, operated under acidic conditions because both bioelements used in the BFCs, viz. cellobiose dehydrogenase $(\mathrm{CDH})$ from Dichomera saubinetii (DsCDH) [11] or from Trametes villosa (TvCDH) [12] and laccase (Lc) from Trametes hirsuta (ThLc) [11] or from Cerena unicolor $(\mathrm{CuLc})$ [12], have their bioelectrocatalytic activity optima at acidic $\mathrm{pH}$ values [14, 15].

$\mathrm{CDH}$ is an extracellular enzyme produced by a variety of different fungi. The enzyme consists of two domains connected by a linker region. The catalytic domain contains one flavin adenine

[*] Corresponding author,sergey.shleev@mah.se 


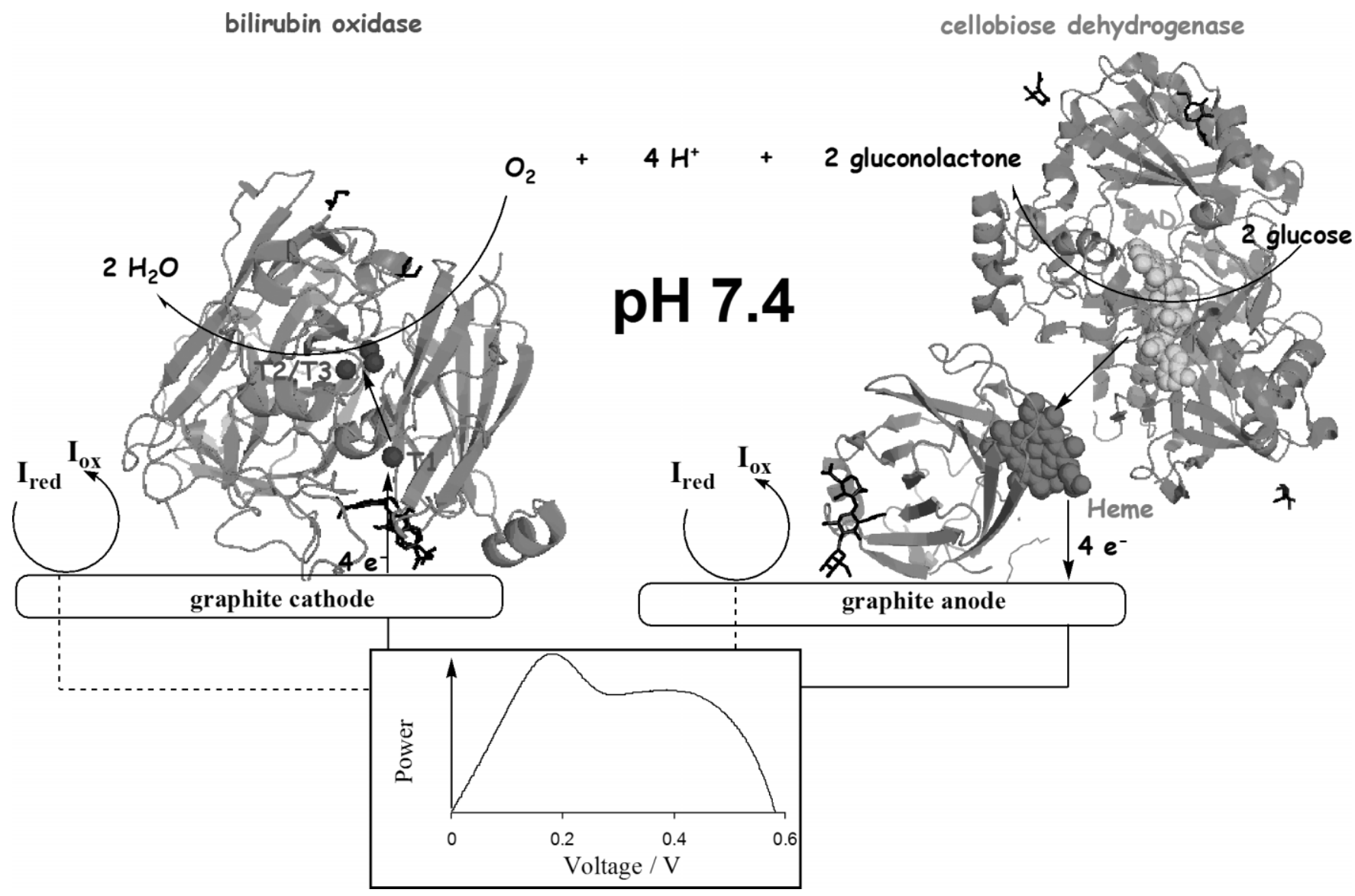

Fig. 1 A principal scheme of a mediator-, compartment- and soluble cofactor-less glucose- $\mathrm{O}_{2} \mathrm{BFC}$ operating in human serum and chloride-containing neutral buffers. The three-dimensional structure of $B O x$ was visualised based on the structures of $B$. subtilis $L c$ (PDB 1UVW) using PyMOL v. 0.99. The flavin and heme domains of Phanerochaete chrysosporium CDH (PDB 1D7D and PDB INAA, respectively) represent the possible structure of CFCDH. The protein globules are given as green ribbons and strands, carbohydrates are presented as black sticks, the four copper ions of $B O x$ are shown as blue spheres, the FAD in CDH - yellow spheres, and the heme - red spheres.

dinucleotide (FAD) and the heme domain contains one heme $b$ as cofactors (Figure 1, right part). $\mathrm{CDH}$ oxidises cellodextrins and lactose at the FAD domain and may, depending on its origin, also oxidise monosaccharides such as glucose [16]. The reduced FAD domain can be reoxidised directly by various electron acceptors or the electrons can be sequentially transferred to the heme domain, which in turn donates the electrons directly to the electrode acting like a $1 \mathrm{e}^{-}$acceptor [17].
Our preliminary intensive studies allowed us to isolate and purify a new $\mathrm{CDH}$ from the ascomycete Corynascus thermophilus (CtCDH), which has, in contrast to DsCDH and TvCDH used in the previously designed BFCs [14, 15] (Table 1), a high catalytic activity for glucose oxidation at neutral $\mathrm{pH}$ values.

$\mathrm{BMCO}$ is a group of copper-containing enzymes, such as ascorbate oxidase (AOx), bilirubin oxidase (BOx), sulochrin

Table 1 Comparison of CDH/BMCO-based BFCs.

\begin{tabular}{|c|c|c|c|c|c|c|c|}
\hline $\mathrm{BFC}$ & Anode/cathode & Conditions & $\begin{array}{l}\text { Open circuit } \\
\text { voltage }(V)\end{array}$ & $\begin{array}{l}\text { Cell voltage } \\
\text { (V) }\end{array}$ & $\begin{array}{l}\text { Power output } \\
\left(\mu \mathrm{Wcm}^{-2}\right)\end{array}$ & $\begin{array}{l}\text { Operation } \\
\text { half-period }(\mathrm{h})\end{array}$ & Ref. \\
\hline $\begin{array}{l}\text { Glucose } / \mathrm{O}_{2} \\
5 \mathrm{mM} / 0.25 \mathrm{mM}\end{array}$ & DsCDH-DET/ThLc-DET & $\mathrm{Cl}^{-}$-free buffer, $\mathrm{pH} 4.5$ & 0.73 & $>0.5$ & $>5$ & $>38$ & [14] \\
\hline $\begin{array}{l}\text { Cellobiose } / \mathrm{O}_{2} \\
5 \mathrm{mM} / 0.25 \mathrm{mM}\end{array}$ & DsCDH-DET/ThLc-DET & $\mathrm{Cl}^{-}$-free buffer, $\mathrm{pH} 4.5$ & 0.76 & 0.55 & 11 & Not reported & [14] \\
\hline $\begin{array}{l}\text { Lactose } / \mathrm{O}_{2} \\
5 \mathrm{mM} / 0.25 \mathrm{mM}\end{array}$ & DsCDH-DET/ThLc-DET & $\mathrm{Cl}^{-}$-free buffer, $\mathrm{pH} 4.5$ & 0.77 & 0.55 & 15 & Not reported & [14] \\
\hline $\begin{array}{l}\text { Lactose } / \mathrm{O}_{2} \\
34 \mathrm{mM} / 0.25 \mathrm{mM}\end{array}$ & TvCDH-MET/CuLc-MET & $\mathrm{Cl}^{-}$-free buffer, $\mathrm{pH} \sim 4$ & 0.6 & $<0.3$ & $<2$ & Not reported & [15] \\
\hline $\begin{array}{l}\text { Glucose } / \mathrm{O}_{2} \\
5 \mathrm{mM} / 0.25 \mathrm{mM}\end{array}$ & $\mathrm{CtCDH}-\mathrm{DET} / \mathrm{M} v \mathrm{BO} \mathrm{x}-\mathrm{DET}$ & PBS, pH 7.4 & 0.62 & 0.37 & 3 & $>6$ & Present study \\
\hline $\begin{array}{l}\text { Glucose } / \mathrm{O}_{2} \\
\sim 5 \mathrm{mM} / \sim 0.25 \mathrm{mM}\end{array}$ & $\mathrm{CtCDH}-\mathrm{DET} / \mathrm{MvBOx}-\mathrm{DET}$ & Human serum & 0.58 & 0.19 & 4 & $<2$ & Present study \\
\hline
\end{tabular}


oxidase (SOx), Lc and ceruloplasmin (Cp), catalysing the oxidation of different organic and inorganic compounds with the concomitant reduction of $\mathrm{O}_{2}$ to $\mathrm{H}_{2} \mathrm{O}$ at different $\mathrm{pH}$ optima. The substrate specificity of these enzymes can be reflected in their trivial names, e.g. BOx is responsible for the oxidation of bilirubin to biliverdin $[18,19]$. Any crystal structure of BOx has not yet been published; however, the biochemical, spectral, electrochemical and kinetic characterisations of Myrothecium verrucaria BOx (MvBOx) have been done and some primary structures of $\mathrm{BOx}$ are also available (Table 2). Based on the similarity between BOx and other $\mathrm{BMCO}$ regarding their main biochemical, spectral and kinetic properties [18, 19], as well as in their primary structures (Table 2), it is widely held that the catalytic site of BOx consists of four copper ions per molecule, classified into three types denoted as $\mathrm{T} 1, \mathrm{~T} 2$ and $\mathrm{T} 3$. The $\mathrm{T} 2$ and $\mathrm{T} 3$ sites form a trinuclear cluster, where one molecule of $\mathrm{O}_{2}$ is bound and reduced to two $\mathrm{H}_{2} \mathrm{O}$ molecules [18]. The mononuclear T1 copper is able to accept electrons from reduced substrates (homogeneous reactions $[18,19]$ ) or electrodes (heterogeneous reactions $[13,20])$, which in turn are transmitted to the trinuclear centre via the highly conserved Cys-2His electron transfer (ET) pathway across a distance of $\sim 13 \AA$. Such ligand arrangements are found in the structures of AOx [21], Lc [22] and Cp [23], and are also hypothesised to exist in BOx (Table 2; Figure 1, left part).

It should be emphasised that some characteristics of fungal BOx are very promising to design efficient and potentially implantable biocathodes. First, fungal BOx constitute high redox potential BMCO [24]. Second, these enzymes are not so strongly inhibited by chloride ions $\left(\mathrm{Cl}^{-}\right)$and they remain very active at neutral $\mathrm{pH}$, two properties which are shared with the low redox potential BMCO, e.g. plant and bacterial Lc. Indeed, in Figure 1 (left part) the three-dimensional structure of $\mathrm{BOx}$ is visualised using the available crystal structure from Bacillus subtilis Lc (BsLc), since the primary structures of both bacterial and fungal enzymes are also quite similar (Table 2).

Below, we describe the fabrication and characterisation of the very first mediator and cofactor free glucose $/ \mathrm{O}_{2}$ BFC based on adsorbed enzymes exhibiting direct anodic and cathodic bioelectrocatalysis, i.e. fungal $\mathrm{Ct} C \mathrm{CDH}$ and $\mathrm{Mv} \mathrm{BOx}$, operating in neutral chloride-containing buffers as well as in human serum (Figure 1).

Table 2 Comparison between the amino acid subsequences of $M v B O x$ and B. subtilis Cota Lc.

\begin{tabular}{|c|c|}
\hline Enzyme & Copper site subsequences \\
\hline \multirow[t]{4}{*}{ BOx (BAA02123, BAA03166) } & ${ }^{131} \mathrm{~V} \mathrm{H} \mathrm{L} \mathrm{H} \mathrm{G}{ }^{135}$ \\
\hline & ${ }^{169} \mathrm{~L}$ W Y H D H A M ${ }^{176}$ \\
\hline & ${ }^{435} \mathrm{~T}$ H P I H I H L L ${ }^{442}$ \\
\hline & ${ }^{494} \mathbf{H} \overline{\mathrm{C}}$ H N L I H E D H D M M M ${ }^{506}$ \\
\hline \multirow[t]{4}{*}{ Cota Lc (PDB 1UVW) } & ${ }^{104} \mathrm{~V} \bar{H} \mathrm{~L}$ H G ${ }^{108}$ \\
\hline & ${ }^{150} \mathrm{~L}$ W Y H D H A M ${ }^{157}$ \\
\hline & ${ }^{418}$ T H P I H I H L L ${ }^{425}$ \\
\hline & ${ }^{491} \mathbf{H} \overline{\mathrm{C}} \mathbf{H}$ N L I $\underline{H}$ E D H D $\underline{\mathrm{M}} \mathrm{M}^{503}$ \\
\hline
\end{tabular}

The ligands of the $\mathrm{T} 1, \mathrm{~T} 2$ and $\mathrm{T} 3$ coppers are underlined, italicised and bolded, respectively.

\section{Experimental}

\subsection{Chemicals}

Unless otherwise specified, all chemicals were purchased from Sigma-Aldrich GmbH (Schnelldorf, Germany). All solutions were prepared using water purified with PURELAB UHQ II system from ELGA Labwater (High Wycombe, UK) or with a Milli-Q system (Millipore, Milford, CT, USA).

\subsection{Enzymes}

MvBOx was kindly provided by Amano Enzyme Ltd. (Nagoya, Japan), stored at $-20^{\circ} \mathrm{C}$, and used without further purification. $\mathrm{CtCDH}$ was purified from the culture supernatant of the ascomycete C. thermophilus, CBS 405.69 obtained from the Centralbureau voor Schimmelcultures (Baarn, The Netherlands). Cultivation and purification of the enzyme were similar to previously reported protocols for Myriococcum thermophilum $\mathrm{CDH}$ [17]. The homogeneous preparation of the enzyme was stored in a $50 \mathrm{mM}$ acetate buffer, $\mathrm{pH} 5.5$ at $-80{ }^{\circ} \mathrm{C}$.

\subsection{BOx Catalytic Assay}

The catalytic activity of $\mathrm{MvBOx}$ in the absence and presence of urea, $\mathrm{HCO}^{3-}, \mathrm{Mg}^{2+}$ and $\mathrm{Ca}^{2+}$ was determined spectrophotometrically (UV-Vis spectrophotometer Anthelie Advanced, Topac Inc., Cohasset, MA, USA) in a reaction medium containing $2 \mathrm{mM} \mathrm{2,2'-azino-bis(3-ethylbenzthiazo-}$ line-6-sulphonic acid) (ABTS, $\varepsilon=36,000 \mathrm{M}^{-1} \mathrm{~s}^{-1}$ ) or $5 \mathrm{mM}$ ferrocyanide $\left(\mathrm{K}_{4}\left[\mathrm{Fe}(\mathrm{CN})_{6}\right], \quad \varepsilon=1,040 \mathrm{M}^{-1} \mathrm{~s}^{-1}\right) \quad$ in $10 \mathrm{mM}$ phosphate buffer (PB) pH 7.4, at room temperature. The volume of the reaction mixture was $1 \mathrm{~mL}$ and the concentrations of different compounds in the reaction medium corresponded to their physiological concentration in human serum (vide infra).

\subsection{Electrochemical Measurements}

\subsubsection{Electrode Preparation}

The enzyme-modified electrodes serving as working electrodes were made from rods of spectrographic graphite electrodes (SPGE, Ringsdorff Werke GmbH, Bonn, Germany, type RW001, $3.05 \mathrm{~mm}$ in diameter). The surface of the SPGE was prepared by first polishing with fine emery paper (Tufback Durite, P1200), then thoroughly rinsed with Millipore water and finally allowed to dry.

\subsubsection{Electrode Modification}

The biocathodes and the bioanodes were prepared by placing an aliquot of $10 \mu \mathrm{L}$ of enzyme solution (BOx, $10 \mathrm{mg} \mathrm{mL}^{-1}$, $\mathrm{CDH}, 7.2 \mathrm{mg} \mathrm{mL}^{-1}$ ) on the electrode surface and the solutions were air-dried at room temperature for $20 \mathrm{~min}$. Before use, the electrodes were rinsed with Milli-Q water to remove weakly adsorbed enzyme. 


\subsubsection{Electrolytes}

The main buffer was phosphate-buffered saline (PBS; $2 \mathrm{~g}$ of $\mathrm{KCl}, 80 \mathrm{~g}$ of $\mathrm{NaCl}, 17.8 \mathrm{~g}$ of $\mathrm{Na}_{2} \mathrm{HPO}_{4} \cdot 2 \mathrm{H}_{2} \mathrm{O}, 2.4 \mathrm{~g}$ of $\mathrm{KH}_{2} \mathrm{PO}_{4}$ in $1 \mathrm{~L}$ of Milli-Q $\mathrm{H}_{2} \mathrm{O}$, sterilised by autoclaving), $\mathrm{pH}$ 7.4, with or without $5 \mathrm{mM}$ glucose, which was dissolved in the buffer a few hours before use to allow mutarotational equilibrium. Human serum, originated from one apparently healthy male volunteer, was prepared as known in the arts and stored at $+4{ }^{\circ} \mathrm{C}$ until use. For serum preparation, 9NC tubes from BD Vacutainer ${ }^{\circledR}$ (Plymouth, UK) were used. The serum was assumed to have a total protein, glucose, dissolved oxygen, urea, $\mathrm{HCO}^{3-}, \mathrm{Mg}^{2+}$ and $\mathrm{Ca}^{2+}$ concentrations of about $70 \mathrm{mg} \mathrm{mL}^{-1}, 1 \mathrm{mg} \mathrm{mL}^{-1}$, and $8 \mathrm{mg} \mathrm{L}^{-1}, 30 \mathrm{mg} \mathrm{L}^{-1}$, $1530 \mathrm{mg} \mathrm{L}^{-1}, 1 \mathrm{mg} \mathrm{L}^{-1}$ and $1 \mathrm{mg} \mathrm{L}^{-1}$, respectively [25-27]. The maximum physiological concentrations of two main possible interfering compounds (I, Figure 1), such as ascorbic and uric acids, were assumed to be 0.11 and $4.0 \mathrm{mM}$, respectively [27].

\subsubsection{Voltammetry}

Linear scan voltammograms and cyclic voltammograms (CVs) were recorded with a scan rate of 1 and $10 \mathrm{mV} \mathrm{s}^{-1}$ in an electrochemical cell of $50 \mathrm{~mL}$ containing a $\mathrm{Ag}|\mathrm{AgCl}| \mathrm{KCl}_{\text {sat }}$ (197 mV vs. NHE) reference electrode (Radiometer, Copenhagen, Denmark) and a platinum foil counter electrode operated by an electrochemical analyser (BAS CV 50W, Bioanalytical Systems, West Lafayette, IN, USA).

\subsubsection{Studies of pH-profiles of the Enzymes Absorbed on SPGE}

The CDH-modified SPGE was fitted into a Teflon holder and inserted into an electrochemical flow cell. The enzyme electrode was used as the working electrode, a $\mathrm{Ag} \mid \mathrm{AgCl}$ $(0.1 \mathrm{M} \mathrm{KCl})$ electrode as the reference electrode and a platinum wire served as the auxiliary electrode. The electrodes were connected to a three-electrode potentiostat (Zäta Electronics, Lund, Sweden). A 0.1 M PB was used as the carrier and was propelled by a Gilson peristaltic pump (Minipulse 2, Villiers-le-Bel, France) at a flow rate of $0.5 \mathrm{~mL} \mathrm{~min}^{-1}$. A working potential of $+300 \mathrm{mV}$ versus $\mathrm{Ag} \mid \mathrm{AgCl}$ was applied to the working electrode [28]. One hundred microliters of a $20 \mathrm{mM}$ glucose solution in buffer were injected into the carrier stream via a LabPRO six-port Rheodyne injection valve (PR700-100-01, Rheodyne, CA, USA) and the output signal was recorded on a strip chart recorder (Kipp and Zonen, type BD111, Delft, The Netherlands).

The dependence of the registered bioelectrocatalytic currents of $\mathrm{O}_{2}$ reduction by BOx-modified SPGE on solution $\mathrm{pH}$ was studied previously [29].

\subsubsection{Open Circuit Potential Measurements}

For open circuit potential measurements, an Autolab PGSTAT 30 (EcoChemie, Utrecht, The Netherlands) equipped with GPES 4.9 software was used. The reference electrode was a $\mathrm{Ag}|\mathrm{AgCl}| \mathrm{KCl}_{\text {sat }}$ electrode and the enzyme-modified electrodes were used as the indicator electrodes placed in a one-compartment $50 \mathrm{~mL}$ electrochemical cell. The equilibrium potential values were registered under air saturated conditions.

\subsubsection{Studies of the Biofuel Cell Performance}

In BFC studies, the Autolab PGSTAT 30 was used in potentiostatic mode. Polarisation curves were recorded at $1 \mathrm{mV} \mathrm{s}^{-1}$ connecting the bioanode (CDH-modified SPGE) as the working electrode and the biocathode (BOx-modified SPGE) as a combined reference and counter electrode. For the time stability tests, an external load of $1 \mathrm{M} \Omega$ was connected between the two electrodes and the potential was measured with time without stirring. The power output of the cells in stability tests was calculated from the potential and resistance values according to Ohm's law. In this work all potentials are given versus NHE.

\section{Results and Discussion}

To fabricate a simple BFC producing electric power based on DET bioelectrocatalytic reactions occurring on both the anode and the cathode parts, two bioelements highly active at neutral $\mathrm{pH}$ (Figure 2), namely $\mathrm{Ct} \mathrm{CDH}$ and $\mathrm{MvBOx}$, were exploited (Figure 1). One of the most attractive electrode elements for a potentially implantable BFC is a carbon material, which is cheap, abundant and biocompatible. To design this BFC, SPGE were chosen, as such electrodes are well-characterised [30] and widely used for bioelectrochemical studies of variety of enzymes including different $\mathrm{CDH}[17,28,31,32]$ and BOx [20,29], on which both bioelements showed excellent DET-based bioelectrocatalysis (Figures 2 and 3).

The proposed mechanisms of the bioelectrocatalytic reactions for both $\mathrm{CDH}$ and $\mathrm{BOx}$ directly adsorbed on SPGEs are

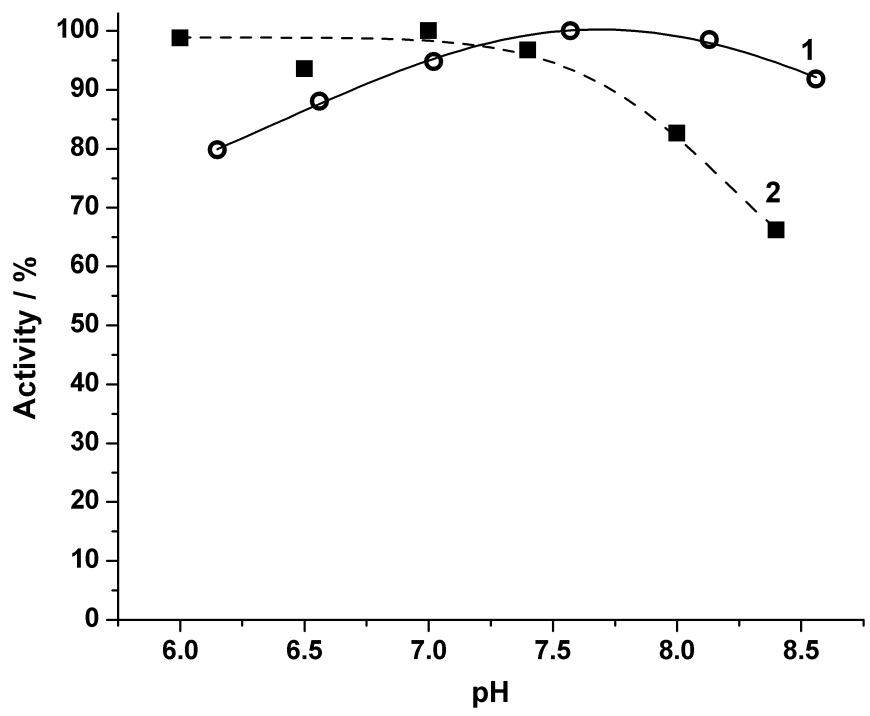

Fig. 2 Relative dependence of DET-based bioelectrocatalytic current on $\mathrm{pH}$ at $\mathrm{CHCDH}$ - (circles, curve 1) and MvBOx-modified SPGE (squares, curve 2). 


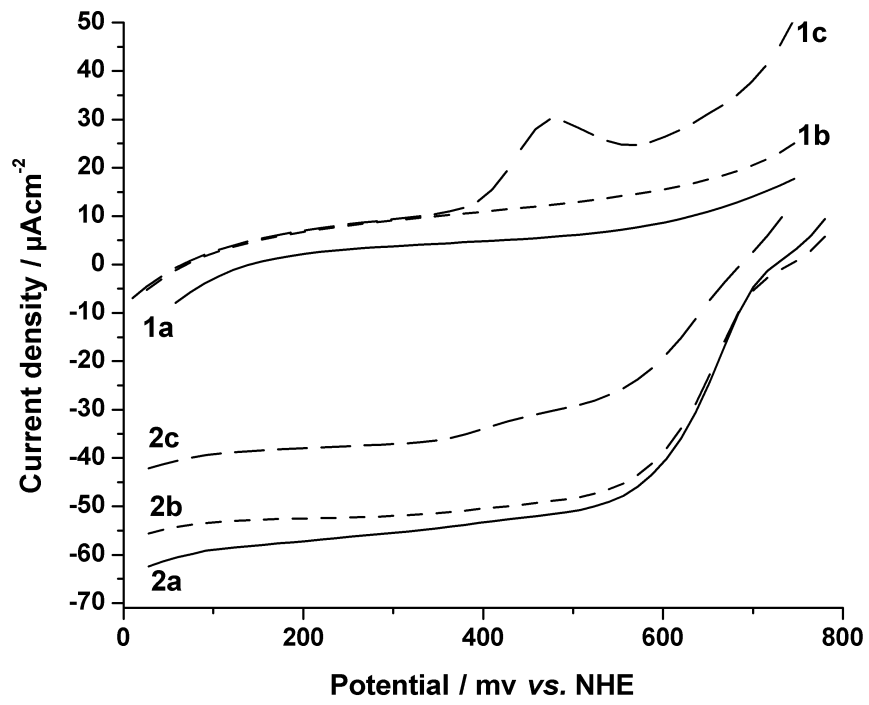

Fig. 3 Linear sweep voltammograms of $\mathrm{CDH}$ - (curves 1) and BOx-modified (curves 2) electrodes. The measurements were performed in batch mode in air-saturated serum (curves c) and PBS with (curves b) and without (curves a) $5 \mathrm{mM}$ glucose.

described in our previous papers [11-13, 20]. A principal scheme of the designed BFC (Figure 1) is therefore similar to that of the already fabricated and characterised BFC operating in acidic solutions [14]. The major difference and novelty of the newly fabricated device is its ability to produce electric power in neutral chloride-containing solutions including complex biological fluids, such as human serum (vide infra).

As can be seen from the voltammograms (Figure 3), electrocatalytic currents at the electrodes modified with the enzymes start at 75 and $720 \mathrm{mV}$ versus NHE for the CtCDHand MvBOx-modified SPGEs, respectively. The starting potentials for $\mathrm{O}_{2}$ bioelectroreduction (Figure 3) and the steady-state potential of MvBOx-modified SPGE (Table 3) in the presence of $\mathrm{O}_{2}$ coincide well at about $720 \mathrm{mV}$. This value is quite close to the half-wave potential of bioelectroreduction of $\mathrm{O}_{2}$ (Figure 3), which is equal to the redox potential of the T1 site of $\mathrm{MvBOx}, 670 \mathrm{mV}$ versus NHE [24], the primary electron acceptor of the enzyme. The redox potential of the heme group, the electrochemically active domain of $\mathrm{CtCDH}$ acting as the electron donor to the bioanode, is not yet known. However, based on the starting potentials of glucose bioelectrooxidation, on the steady-state potentials of $\mathrm{CtCDH}$-modified SPGEs in the absence and presence of glucose (Table 3), as well as on previous studies of other $\mathrm{CtCDHs}$ from different fungi $[11,12,14,17,28,32$, 33], one can assume that the redox potential of the heme group is close to $150 \mathrm{mV}$ versus NHE. The differences between the steady-state potentials of the

Table 3 Open circuit potentials ( $\mathrm{mV}$, vs. NHE) of SPGEs modified with $\mathrm{CDH}$ or $\mathrm{BOx}$ in air-saturated liquids.

\begin{tabular}{lll} 
Conditions & Anode & Cathode \\
\hline PBS, pH 7.4 & 155 & 720 \\
PBS, pH 7.4 + 5 mM glucose & 110 & 725 \\
Blood serum & 100 & 680
\end{tabular}

MvBOx- and CtCDH-SPGEs determine the maximal open circuit potential of the BFC operating in glucose-containing PBS and human serum, i.e. ca. $0.62 \mathrm{~V}$ and $0.58 \mathrm{~V}$, respectively (Table 1).

The limiting biocatalytic current densities of the BOxbased biocathode significantly differed in buffer solution versus human serum, to some extent in agreement with previously published data concerning the reversible deactivation or even irreversible damage of BOx-catalysed homogeneous and heterogeneous reactions by serum components, e.g. the combination of urate $/ \mathrm{O}_{2}$ [34-36]. In contrast, the current output from the bioanode was almost the same in both serum and glucose-containing PBS solution (Figure 3).

The starting potentials for $\mathrm{O}_{2}$ bioelectroreduction (Figure 3), the steady-state potential of $\mathrm{MvBOx}$-modified SPGE (Table 3) and the open circuit potential of the BFC were all decreased by ca. $40 \mathrm{mV}$ in serum compared to simple neutral chloride-containing buffer solutions because of partial enzyme inhibition by several compounds presented in a complex natural buffer solution - human serum. Many organic compounds and inorganic ions presented in serum could affect the specific activity of $\mathrm{MvBOx}$, e.g. urea, $\mathrm{HCO}_{3}^{-}, \mathrm{Mg}^{2+}$, $\mathrm{Ca}^{2+}$ (Table 4). It should be emphasised that the power output of the BFC increased insignificantly, when the glucose containing PBS was strongly mixed. This indicates a reaction limitation of the whole system by the catalytic activity of the immobilised enzymes and only to a limited extent by mass transfer limitation. Thus, partial inhibition of the enzyme resulted in detectable changes of the bioelectrocatalytic activity of adsorbed $\mathrm{BOx}$, which influenced some basic parameters of $\mathrm{CDH} / \mathrm{BOx}$-based BFC (vide infra) including its open circuit potential.

Figure 4 shows the dependence of the cell voltage versus the power density of the designed BFC. In a quiet glucosecontaining buffer solution, the maximum power density was $3.0 \mu \mathrm{W} \mathrm{cm}{ }^{-2}$ at $370 \mathrm{mV}$ of the cell voltage. The shape of the curve was very similar to the previously reported voltage/ power dependences of CDH/BMCO-based devices [14, 15]. The electrical power produced by $\mathrm{CtCDH}-\mathrm{DET} / \mathrm{MvBOx}$-DET BFC was originated from two bioelectrocatalytic processes occurring simultaneously on the electrodes, viz. bioelectrooxidation of glucose on the anode and bioelectroreduction of $\mathrm{O}_{2}$ on the cathode. In a quiet serum, one of the maxima on the voltage/power curve was also close to $3.0 \mu \mathrm{W} \mathrm{cm}{ }^{-2}$ (Figure 4). However, an additional maximum at $190 \mathrm{mV}$ of the cell voltage appeared with the highest power density of BFC close to $4 \mu \mathrm{W} \mathrm{cm}{ }^{-2}$. Detailed electrochemical studies of

Table 4 Catalytic activity of $\mathrm{MrBOx}\left(k_{\mathrm{obs}}, \mathrm{s}^{-1}\right)$ in the absence and presence of different organic and inorganic compounds.

\begin{tabular}{lll} 
Compound & ABTS & $\mathrm{K}_{4}\left[\mathrm{Fe}(\mathrm{CN})_{6}\right]$ \\
\hline $\mathrm{PB}, \mathrm{pH} 7.4$ & 31 & 63 \\
Urea & 25 & 56 \\
$\mathrm{HCO}_{3}^{-}$ & 21 & 54 \\
$\mathrm{Mg}^{2+}$ & 31 & 55 \\
$\mathrm{Ca}^{2+}$ & 27 & 53
\end{tabular}




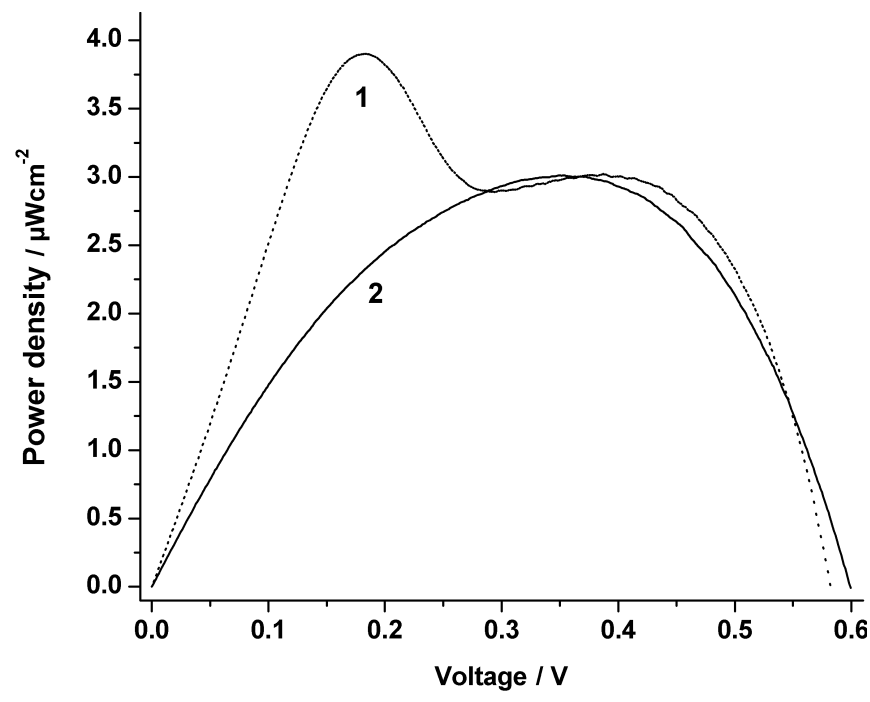

Fig. 4 Dependence of power density on operating voltage for the membrane-less BFC in quiet conditions. As fuels human serum (curve 1) and $5 \mathrm{mM}$ glucose-containing PBS (curve 2) were used.

the anodic and the cathodic electrochemical reactions (Figures 3 and 5) explain significant differences in the BFC performance in complex human serum versus simple glucosecontaining PBS solution (Figure 5).

In addition to the bioelectrocatalytic processes of glucose oxidation and $\mathrm{O}_{2}$ reduction, non-enzymatic electrocatalytic reactions occur on both bioelectrodes submerged in serum. These non-enzymatic reactions correspond to electrochemical transformations of different electroactive compounds, e.g. electro-oxidation of uric and ascorbic acids (Figure 5), which are present in human serum at high physiological concentrations [27]. The peak height of the electro-oxidation wave of uric acid at a concentration of $0.4 \mathrm{mM}$ (i.e. at normal concentration in serum of an adult male) coincides quite well with

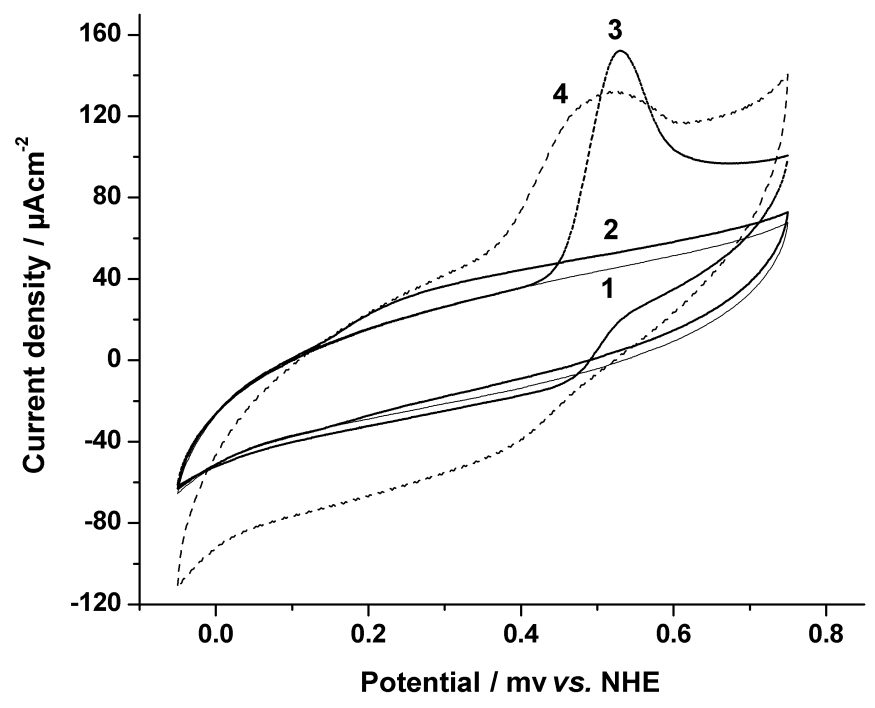

Fig. $5 \mathrm{CV}$ s of an SPGE electrode in air-saturated PBS (curve 1), PBS with $0.11 \mathrm{mM}$ ascorbate (curve 2), PBS with $0.4 \mathrm{mM}$ urate (curve 3) and human serum (curve 4). the peak height obtained by electro-oxidising serum from the apparently healthy male volunteer (cf. curves 3 and 4 in Figure 5). The electro-oxidation of ascorbic acid on SPGE starts at a potential of $140 \mathrm{mV}$ versus NHE (Figure 5, curve 2). Both the starting potentials and current densities on the CVs of the SPGEs submerged in PBS with ascorbic acid and human serum coincide well in the potential window of 140 $250 \mathrm{mV}$, i.e. at the initial part of the CVs recorded with the SPGE in PBS with ascorbic acid at a normal physiological concentration (cf. curves 2 and 4 in Figure 5). The shape of the $\mathrm{CV}$ of the SPGE in serum along with the significant current densities of the anodic and especially the cathodic waves (curve 4 in Figure 5) compared to the CVs of the SPGE recorded in PBS with ascorbic and uric acids point to the fact that some other electrochemically active compounds might be present in human serum. The nature of these compounds is unclear. However, the non-enzymatic electrochemical reactions of interfering substances (I; Figure 1) along with the bioelectrocatalytic processes occurring simultaneously on the electrode surfaces result in an additional maximum of $0.19 \mathrm{~V}$ on the power-voltage curve with the highest maximal power density of the device close to $4 \mu \mathrm{W} \mathrm{cm} \mathrm{cm}^{-2}$ (Figure 4).

An important factor of the designed BFC is its operational stability because a potentially implantable BFC should have a long lifetime. An estimated half-life of the BFC operating in simple PBS and human serum are ca. 6 and $1.5 \mathrm{~h}$, respectively (Figure 6).

Both $\mathrm{CDH}$ and $\mathrm{BOx}$ are known to be stable biocatalysts. The substantial loss of the BFC power in the first few hours of operation is mostly related to the desorption of loosely bound enzymes from both bioelectrodes [14]. In serum, which has a very high concentration of human proteins and low molecular weight organic and inorganic compounds, two additional processes had a negative effect on the operating stability of BFC, viz. possible exchange of non-covalently bound

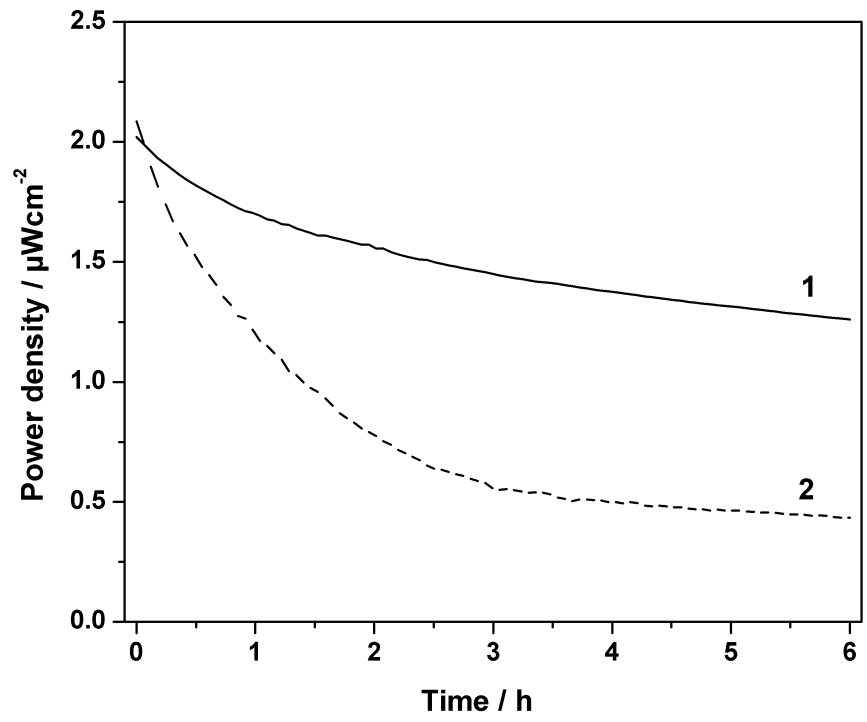

Fig. 6 Variation of power density of the BFC with time in air-saturated $\mathrm{PBS}$, pH 7.4, with $5 \mathrm{mM}$ glucose (curve 1) and human serum (curve 2). 
enzymes ( $\mathrm{CDH}$ and $\mathrm{BOx}$ ) from both bioelectrodes and reversible deactivation/irreversible damage of the biocathode by the combination of urate $/ \mathrm{O}_{2}$ [34-36]. In addition, inhibition of adsorbed $\mathrm{BOx}$ by inorganic ions could also decrease the stability of the device (vide supra). After equilibration, i.e. enzyme desorption, inhibition, damage and exchange, the signal of the cell in both electrolytes, viz. buffer and even serum, is still substantial and it has reached a stabilised level (Figure 6).

In the future, covalent binding of $\mathrm{CDH}$ and $\mathrm{BOx}$ along with the usage of nanotechnological achievements might significantly improve both the operational stability and the power density of the BFC, e.g. as it was recently achieved for CDH-based bioanodes [37, 38] and Lc-based biocathodes [39].

\section{Conclusion}

Herein, we report the fabrication and characterisation of a mediator and soluble cofactor free, non-compartmentalised, glucose $/ \mathrm{O}_{2}$ BFC operating in human serum and PBS glucosecontaining solutions. BFCs designed in this work and in our previous studies [14] can serve as simple not yet optimised models to construct non-toxic potentially implantable miniature DET-based glucose $/ \mathrm{O}_{2}$ BFCs working in physiological fluids of different compositions and $\mathrm{pHs}$.

\section{Acknowledgments}

The authors thank Amano Enzyme Europe Ltd. for 'Amano 3' preparation of Myrothecium verrucaria BOx. The authors also thank Anna Gustafsson (Malmö University, Sweden) for blood collection and Marius Dagys (Institute of Biochemistry, Lithuania) for Myrothecium verrucaria BOx catalytic assay. The work was financially supported by the Swedish Research Council (621-2007-4124 and 621-2008-3713), the Austrian Science Fund (project L-395 B11) and the European Commission (MEST-CT-2004-514743 and NMP4-SL-2009229255).

\section{References}

[1] M. Beltzer, J. S. Batzold, 4th Proc. Intersoc. Energy Convers. Eng. Conf., Washingtom, DC, USA, 1969, p. 354.

[2] N. Mano, F. Mao, A. Heller, J. Am. Chem. Soc. 2002, 124, 12962.

[3] S. C. Barton, J. Gallaway, P. Atanassov, Chem. Rev. 2004, 104, 4867.

[4] A. Heller, Phys. Chem. Chem. Phys. 2004, 6, 209.

[5] P. Atanassov, C. Apblett, S. Banta, S. Brozik, S. C. Barton, M. Cooney, B. Y. Liaw, S. Mukerjee, S. D. Minteer, Electrochem. Soc. Interface 2007, 16, 28.

[6] M. J. Cooney, V. Svoboda, C. Lau, G. Martin, S. D. Minteer, Energy Environ. Sci. 2008, 1, 320.
[7] M. Zayats, B. Willner, I. Willner, Electroanalysis 2008, 20, 583.

[8] H. Sakai, T. Nakagawa, Y. Tokita, T. Hatazawa, T. Ikeda, S. Tsujimura, K. Kano, Energy Environ. Sci. 2009, 2, 133.

[9] F. Gao, Y. Yan, L. Su, L. Wang, L. Mao, Electrochem. Commun. 2007, 9, 989.

[10] X. Li, L. Zhang, L. Su, T. Ohsaka, L. Mao, Fuel Cells 2009, 9, 85.

[11] A. Christenson, N. Dimcheva, E. Ferapontova, L. Gorton, T. Ruzgas, L. Stoica, S. Shleev, A. Yaropolov, D. Haltrich, R. Thorneley, S. Aust, Electroanalysis 2004, 16,1074 .

[12] L. Gorton, A. Lindgren, T. Larsson, F. D. Munteanu, T. Ruzgas, I. Gazaryan, Anal. Chim. Acta 1999, 400, 91.

[13] S. Shleev, J. Tkac, A. Christenson, T. Ruzgas, A. I. Yaropolov, J. W. Whittaker, L. Gorton, Biosens. Bioelectron. 2005, 20, 2517.

[14] V. Coman, C. Vaz-Dominguez, R. Ludwig, W. Harreither, D. Haltrich, A. L. De Lacey, T. Ruzgas, L. Gorton, S. Shleev, Phys. Chem. Chem. Phys. 2008, 10, 6093.

[15] L. Stoica, N. Dimcheva, Y. Ackermann, K. Karnicka, D. A. Guschin, P. J. Kulesza, J. Rogalski, D. Haltrich, R. Ludwig, L. Gorton, W. Schuhmann, Fuel Cells 2009, 9, 53.

[16] M. Zamocky, R. Ludwig, C. Peterbauer, B. M. Hallberg, C. Divne, P. Nicholls, D. Haltrich, Curr. Protein Pept. Sci. 2006, 7, 255.

[17] W. Harreither, V. Coman, R. Ludwig, D. Haltrich, L. Gorton, Electroanalysis 2007, 19, 172.

[18] E. I. Solomon, U. M. Sundaram, T. E. Machonkin, Chem. Rev. 1996, 96, 2563.

[19] T. Sakurai, K. Kataoka, Chem. Rec. 2007, 7, 220.

[20] P. Ramirez, N. Mano, R. Andreu, T. Ruzgas, A. Heller, L. Gorton, S. Shleev, Biochim. Biophys. Acta 2008, 1777, 1364.

[21] A. Messerschmidt, R. Ladenstein, R. Huber, M. Bolognesi, L. Avigliano, R. Petruzzelli, A. Rossi, A. FinazziAgro, J. Mol. Biol. 1992, 224, 179.

[22] K. Piontek, M. Antorini, T. Choinowski, J. Biol. Chem. 2002, 277, 37663.

[23] P. F. Lindley, G. Card, I. Zaitseva, V. Zaitsev, B. Reinhammar, E. Selin-Lindgren, K. Yoshida, J. Biol. Inorg. Chem. 1997, 2, 454.

[24] A. Christenson, S. Shleev, N. Mano, A. Heller, L. Gorton, Biochim. Biophys. Acta 2006, 1757, 1634.

[25] B. T. Doumas, Clin. Chem. 1975, 21, 1159.

[26] J. A. Falch, M. Mowe, T. Bohmer, Scand. J. Clin. Lab. Invest. 1998, 58, 225.

[27] F. Moussy, D. J. Harrison, D. W. O’Brien, R. V. Rajotte, Anal. Chem. 1993, 65, 2072.

[28] L. Stoica, T. Ruzgas, R. Ludwig, D. Haltrich, L. Gorton, Langmuir 2006, 22, 10801.

[29] S. Shleev, A. El Kasmi, T. Ruzgas, L. Gorton, Electrochem. Commun. 2004, 6, 934. 
[30] H. Jaegfeldt, T. Kuwana, G. Johansson, J. Am. Chem. Soc. 1983, 105, 1805.

[31] T. Larsson, E. Elmgren, S.-E. Lindquist, M. Tessema, L. Gorton, G. Henriksson, Anal. Chim. Acta 1996, 331, 207.

[32] T. Larsson, A. Lindgren, T. Ruzgas, S. E. Lindquist, L. Gorton, J. Electroanal. Chem. 2000, 482, 1.

[33] T. Larsson, A. Lindgren, T. Ruzgas, Bioelectrochemistry 2001, 53, 243.

[34] C. Kang, H. Shin, A. Heller, Bioelectrochemistry 2006, 68, 22.
[35] C. Kang, H. Shin, Y. Zhang, A. Heller, Bioelectrochemistry 2004, 65, 83.

[36] H. Shin, C. Kang, A. Heller, Electroanalysis 2007, 19, 638.

[37] F. Tasca, L. Gorton, W. Harreither, D. Haltrich, R. Ludwig, G. Noll, J. Phys. Chem. 2008, C 112, 13668.

[38] F. Tasca, L. Gorton, W. Harreither, D. Haltrich, R. Ludwig, G. Noll, J. Phys. Chem. 2008, C 112, 9956.

[39] C. Vaz-Dominguez, S. Campuzano, O. Rüdiger, M. Pita, M. Gorbacheva, S. Shleev, V. M. Fernandez, A. L. De Lacey, Biosens. Bioelectron. 2008, 24, 531. 